THE EUROPEAN JOURNAL OF LIFE WRITING VOLUME IX (2020) C115-C128

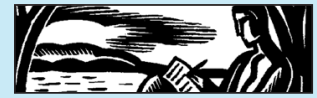

\title{
A View to Distant Hills: Essaying a Grievous Self
}

\section{Myna Trustram}

Manchester School of Art

\section{ABSTRACT}

This is a personal essay that attempts (essays) to understand my repeated contemplation of two landscape paintings in the wake of a bereavement. I have gathered together into a fragmented narrative thoughts and impressions provoked by the paintings and by readings of poetry (Czeslaw Milosz), fiction (Samuel Beckett) and psychoanalysis (Marion Milner and D. W. Winnicott). There is no closure or conclusion to the essay since grief is open and perennial.

Keywords: landscape, grief, Philips Koninck, Samuel Fyzee-Rahamin

Some months after a grievous bereavement I returned to work in a municipal art gallery in the north of England.

At lunch time I would sit in a nearby church along with a few people who appeared to be believers. Sometimes a lay person would arrange the church for a service, placing candles and books in their correct places. There was a sense of preparation rather than arrival, whereas I had arrived in a place I did not want to inhabit. Lighting candles was not part of my Church of England childhood, but I did so now for reasons that felt fraudulent. For a short while I aligned myself with Mary's maternal losses but that also felt fraudulent, for her almighty story was not mine. 
One afternoon I looked for a work in the gallery that might assuage, satisfy and stifle my sadness. I found an oil painting by Philips Koninck, Flat Landscape with a View to Distant Hills, (1648).

A tiny figure, who is holding the hand of a barely-formed child, walks along a remote road that winds around into the distance; a dog runs nearby, chasing birds that fly close to the ground. In the middle distance there are other figures, cattle drovers, hardly discernible. In the far distance two towns, in the further distance, hills looking more like clouds. A dark shadow from the sun falls across the land behind the man and child who walk away from the distant scene, beyond this there is a bright horizontal strip of sunshine. The grey-blue sky takes up a least half of the painting.

The couples move away from each other: the man and child step out of the landscape, the drovers head away into the beyond of flatness, far hills, and a huge sky.

Of all the works in the gallery, I wanted this one alone and began to visit it regularly.

Philips Koninck (1619-1688) was a seventeenth century Dutch artist best known today for his landscapes of which about seventy survive; he was a follower, possibly a pupil, of Rembrandt. As was common in Dutch landscape painting, Flat Landscape is an imagined scene though influenced by his native Gelderland. A catalogue of Koninck's work by Horst Gerson was published in German in 1935 and reprinted in $1980 .{ }^{1}$ In the catalogue the painting is simply titled, Flachlandschaft (Flat Landscape). I do not know when it acquired the more elaborate title. It was bequeathed by Mr and Mrs Ashetton-Bennett to the Manchester Art Gallery in the 1970s.

$*$

Early one new year, flattened by the dead commerce of the post-Christmas city, I went to see the painting. It was close to epiphany. By this time I had stopped working in the Gallery.

That was when I decided to test my love for Flat Landscape. I walked slowly past other works in search of one that might also draw me into elements of my grief that I had tidied away.

I did find another. A watercolour by Samuel Fyzee-Rahamin, Ali Pather, Kashmir (1930). A tiny figure, laden with firewood, walks along a lake in front of huge mountains. It is blue all over, bound by a delicate brown border. 


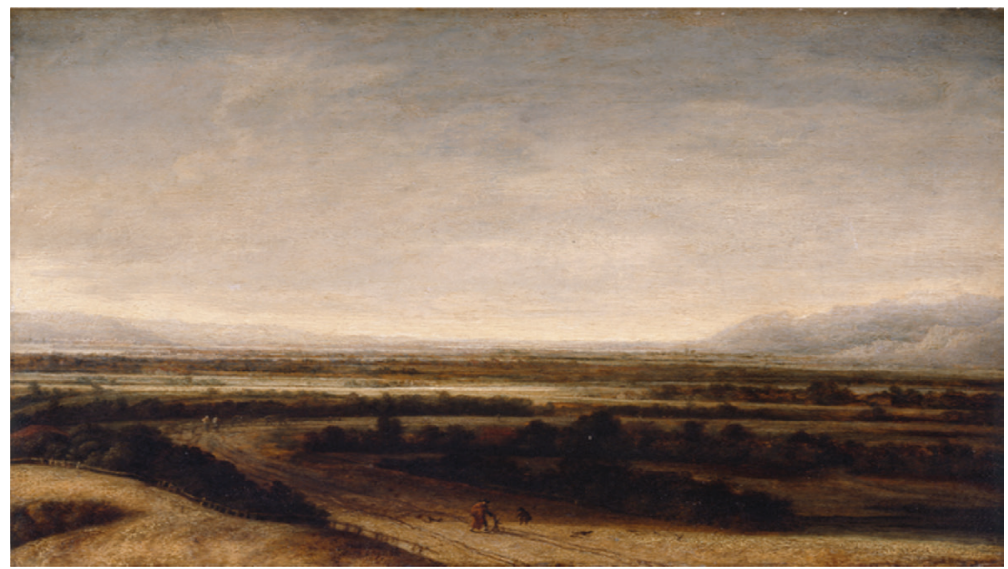

Philips Koninck, Flat Landscape with a View to Distant Hills (1648). Courtesy of Manchester Art Gallery.

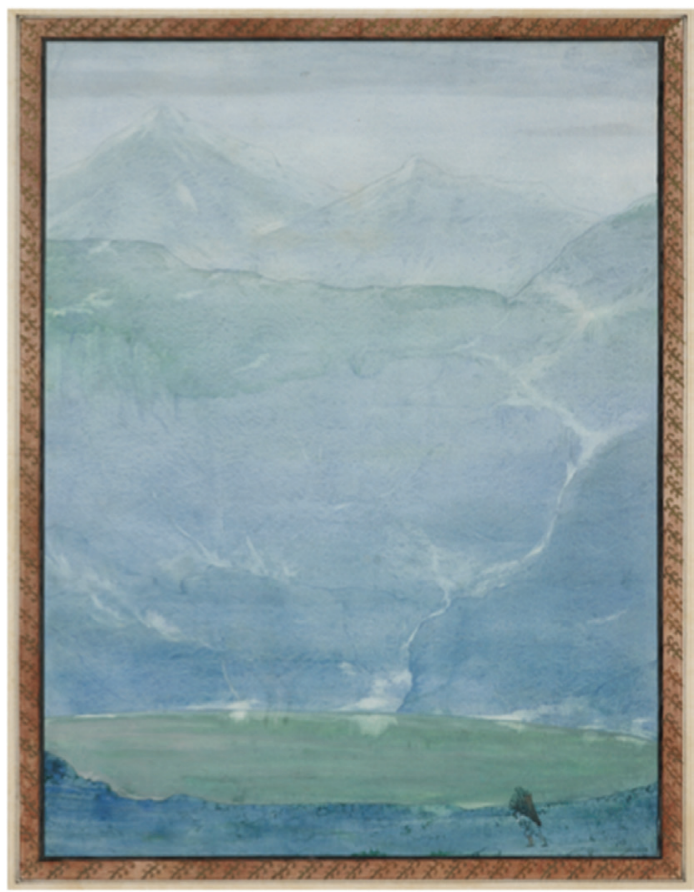

Samuel Fyzee-Rahamin, Ali Pather, Kashmir (1930). Courtesy of Manchester Art Gallery. CEstate of Fyzee-Rahamin. ${ }^{2}$ 
No accident was it that I had found another painting of a man made insignificant by an enormous landscape; each was painted by a man foreign to me, three hundred years apart, and each of a scene also foreign to me, at least one of which was imagined. My choices mirrored my habitual experience of being in the world at a distance from others. Bereavement does not transform you - it pushes you further inside wherever you might already be.

The figures appear to be deep inside their walking, taking little notice of the places they journey through. The stack of firewood on the back of the man in Kashmir is far taller than he, there is hope for warmth though it will burn through quickly; the man in Flat Landscape/Flachlandschaft carries no burden except perhaps the responsibility of a child. To my eyes there is something unlikely about the firewood - scarcity alone must make it worthwhile to carry it so far.

We are not so badly off, if we can

Admire Dutch painting.

So begins Czeslaw Milosz's poem Realism, in which he considers Dutch landscapes and still lifes. ${ }^{3}$ It is not admiration or appreciation (the more usual sentiment when thinking about fine art) that I feel for the Dutch painting, it is something more like attunement. When I can sense a harmony with sculpted forms such as a fence post or mud tracks, and with real things turned into a painting or a poem, then I am not so badly off.

In the same poem Milosz writes of such things as a half-peeled lemon or a loaf of bread:

It is hard not to believe in their lastingness.

In landscape and still life there is a smear of hope. In September stone barns stand in the fields of Swaledale, waiting to house cattle over winter.

Whilst this poem encapsulates all that I might want to write about such things as paintings, loss and language, I need to write words myself for them to do their work of revelation and renewal.

Grace sent a photograph she took in Costa Rica of a flat beach and seascape with white fluffy clouds being sucked away over the horizon. My brother sent photographs of the Welsh Borders.

I am trying to make good an early infant deficit and the crater left behind by the accident. 
Trying to remain alive to others and their children.

I remember pushing her out in a pram for the first time and feeling not quite real, an impostor mother. I told my sister and she said she had also felt this when she first pushed out her son.

Czeslaw Milosz again:

Each of us is so ashamed of his own helplessness and ignorance that he considers it appropriate to communicate only what he thinks others will understand. There are, however, times when somehow we slowly divest ourselves of that shame and begin to speak openly about all the things we do not understand. ${ }^{4}$

I write from a place of incomprehension and walk into the real world of rutted roads. There is understanding that is cognitive and understanding that is forgiving.

With his broad-brimmed hat, his cloak draped over his arm and his hand held out to the child, the man walks with a hopeful flair away from the flatness, perhaps he is going home to a town.

There was no epiphany.

$*$

The painting offered a second chance, another way to frame what had happened, as a dream reframes a life beyond recognition. Perhaps I could be open to unforeseen consequences of the accident.

*

One day, using the psychoanalytic practice of free association, I wrote,

I too am a small figure passing through a remote landscape, unaware of the enormity of my surroundings. The man in the wide-brimmed hat and the poor man laden with firewood enter into me because there are equivalences between us. The paintings draw me into a comforting kind of melancholy.

A nice poetic thought but not true; it was driven by a wish to demonstrate a refined sensibility and to feel better.

Later that day I wrote again.

I am the child, alone with the man. Hold my hand. Make me substantial. I'm hardly there. I am nothing. Is he good or bad, is he taking me away, drawing me away from what I know, away from the two other distant figures, or am I leading him on and away. I am barely there. I lead him. He follows. He takes 
me. To an unknown place. Does he know where we're going? Is he an old man, a young man, a danger, a protector. Tell me.

The whole thing becomes disturbing when I turn my attention to the child and see how I have muddled myself up with them.

I am the child whose hand the man holds. After the accident I asked the man who took us in for hot milk.

Through freely associative writing undertaken when I no longer stand before the paintings, I move closer to imagined and unconscious associations. Essay writing shifts the engagement even further, this time into a state of mind that moves between the real and the imagined as it moves in and out of narrative. When writing in response to art in a freely associative manner and as an essayist, I bring together two elements. Language with its agreed and fixed (though malleable) meanings, and art's plasticity - its symbolic forms that have no agreed meanings and are open to individual use according to one's own emotional landscape, one's forms of and for feeling.

My purpose in writing this essay is not to understand its object - the painting - but to understand my experience of it within the emotional landscape that I bring to it, a process that endeavours to open up rather than to report or close down. What use might I make of the painting?

*

On another day when I returned to Flat Landscape it was gone, replaced by Leonardo drawings from the Royal Collection. This was a reminder, though I hardly needed it, not to presume - even in a museum - that things will continue as they are. I asked if I could see the painting: 'Of course you can. Just make an appointment'.

We went through the heavy door of the basement art store. There it was, laid out on a table waiting for me, it was like meeting someone familiar but in their new house. An affair. For the first time I saw the two distant towns in the top left-hand corner and a stretch of water, or maybe sunlight. I had found the painting again and it was safe to assume it would always be looked after in the gallery.

It wasn't until two years after the disaster that I began to write again, a daily diary: a fragmentary form that turns the rolling forward of the days, months and years into an accumulation of entries, a life into a catalogue. For a while I imagined there to be an affinity between my broken self and the diary's fragmented narrative. In fact, this was an illusion, another nice construction that, having become part of my thinking, became stale and needed to be overcome. 
My contemplation of the painting was not without purpose - I sought relief from intense emotions - but it had something of D. W. Winnicott's "non-purposive being' about it: a state of mind (in an infant or adult) that enables a sense of self to develop. Winnicott develops the idea in the context of child development and an adult's psychoanalytic relationship with an analyst. I want to propose the potential for a greater understanding of bereavement, if not of the self, if you can tolerate periods of purposeless looking. I borrow these ideas from psychoanalysis not with the aim of effecting psychic change, but in order to suggest that, in contemplation of a work of art in a mindless fashion, sensations and thoughts that are not otherwise available from within a habitual and purposeful stance, might just come along.

As I contemplated the paintings, and more so as I write this essay, two books came to mind: Marion Milner's On Not Being Able to Paint (1950) and T.J. Clark's The Sight of Death: An Experiment in Art Writing (2006). ${ }^{6}$ I was drawn to both writers' concentrated and repeated practice of looking at images. Marion Milner's book is applauded as a treatise on creativity in which she describes a method she devised for teaching herself to paint. In a departure from his usual art-historical writing, T. J. Clark wrote a four-month diary about his repeated viewings of two paintings by Nicolas Poussin. They are both chroniclers of a particular kind of looking, whilst it happens, and of what can be seen if one returns to something of the child's view. In my repeated viewings of Flat Landscape, I used practices of repetition, writing and free association to dig into the self that is muddied by grief. I was looking for solace and comprehension; in the event, solace came hand-in-hand with insight, a solace that propels forward rather than returning one to some peaceful cavern.

In The Sight of Death Clark set out to capture 'what occurs in front of paintings more or less involuntarily, not what I think ought to occur'.? Milner's quest was more deeply personal, but they both approached their respective paintings 'absent-mindedly', ${ }^{8}$ without thoughts of the past or future but instead with a concentration on the present, and both found personal meanings.

Milner learned that when she paints she has to plunge into 'a sea of pain', and to risk 'losing one's hold on the solid earth'. ${ }^{9}$ Clark asked whether the return to a painting is because,

\footnotetext{
'there are certain kinds of visual configuration, or incident, or play of analogy, that simply cannot be retained in the memory, or fully integrated into a disposable narrative of interpretation; so that only the physical, literal, dumb act of receiving the array on the retina will satisfy the mind? ${ }^{10}$
} 
I make many returns: to the painting, to the writing, to the reading, to the day of the accident, to the lost one. There are certain kinds of incidents such as fatal accidents that will not fall into a disposable linear narrative but require many loopings back.

As Clark concluded,

'Don't we go back to it because we sense that in it is re-enacted a death or terror we would all like to experience again in this harmless, ordered, palliative mode?'11

Most likely yes, and this is especially apt for the painting he was looking at: Landscape with a Man Killed by a Snake. It is his evocation of the 'harmless, ordered, palliative mode' that rings true and is akin (though no more than that) to the remembering of trauma within the harmless, ordered, hold of the analyst's consulting room. Some visual configurations cannot be retained in the memory because they evoke too much fear if remembered outside of the ordered hold of a painting (or the consulting room). This is not the case with my viewing of Flat Landscape. It might have been, on the contrary, that my return was driven by a wish to see again some order that another has imagined; an order that contains enough mystery but also an alignment with my experience. But I was not consciously aware of this.

The man and the child walk freely along the road, the dog runs, the birds wheel, they are all connected.

According to Elizabeth Bishop:

'What one seems to want in art, in experiencing it, is the same thing that is necessary for its creation, a self-forgetful, perfectly useless concentration. ${ }^{.12}$

And yet the pull is to forget the self that has suffered and to deny her the relief that might come from an intensified sensibility; relief and suffering come perilously close; landscapes - actual and imagined - invite an expansion into feeling and narrative; suffering and sensibility intertwine.

$*$

What if I told you now that the two men in the paintings are women? One holds the hand of a child, another bears a stack of firewood on her back. They would no longer represent something universal and my connection with them would be more intimate; they would no longer be other but 
neither would they be me, they would be more themselves. In Pieter Bruegel's The Hunters in the Snow (1565) there's a woman on a bridge, bearing a load of firewood on her head and wearing an apron which accentuates her womanhood. She is more upright than the man in Kashmir who is bent over by his load, as are Bruegel's returning hunters, weighed down by the hunt, but not their game, which has produced nothing more than a rabbit.

The woman on the bridge and the man in Kashmir have a grace, a steady-footed acceptance of their state.

$*$

One day I went to see the painting but again it wasn't there. I came again some weeks later and it was back with a new caption which said that the minute figures and the dog chasing birds provided a sense of scale. I felt a lift when I saw it again - the town, the shadow that falls across from the right, the weak sunlight on the left, the man and child stepping out of the shadow, the tiny bit of light on the right-hand side of his face and his ankle, the dog's shadow and the man and child's shadow.

Flat landscape with a view to distant hills

Philips Koninck 1619-1688

Koninck's panoramic views were among the most innovative developments in Dutch landscape painting. He was inspired by the broad plains of his native Gelderland, and this subject dominated much of his work.

This early example may show the influence of Rembrandt in its contrast of light and shade. Koninck suggests the expansiveness of the land through horizontal bands of mossy greens and browns The minute figures and the dog chasing birds provide a sense of scale.

Assheton Bennett bequest 1979.46913

$*$

'The finished creation never heals the underlying lack of sense of self'. ${ }^{14}$ Winnicott speaks here about the artist: it is the process of making that matters. But the same applies to the viewer: the repeated viewings matter rather than any discovered meaning. That I look at the paintings and write this essay establishes that there is a ME after the accident. I did survive, though she did not. I had the idea to write the essay. ${ }^{15}$

Once the worst has happened there is an expansion into pure possibility, something of this is heralded in the painting's calm. 
'It was on a road remarkably bare, I mean without hedges or ditches or any kind of edge, in the country, for cows were chewing in enormous fields, lying and standing, in the evening silence. ${ }^{16}$

'But the hat, a town hat, an old-fashioned town hat, which the least gust would carry far away. Unless it was attached under the chin, by means of a string or an elastic. ${ }^{17}$

A copy of the painting lies on my table as I read from Samuel Beckett's novel, Molloy. The detective Moran is on a journey looking for Molloy and is accompanied by his thirteen or fourteen-year-old son. Until this moment I had allowed the essay to arise from unsought associations. Now I searched for connections between the man and boy in the painting and the man and boy in the novel. It felt contrived but once I found a connection between the men that was more than that they are both accompanied by a boy (I had indeed assumed the child in Flat Landscape is a boy), the search lost its awkwardness and moved into greater significance as the two men moved further into my imagination. This happened by means of a raincoat. Moran comments of his son and his raincoat,

instead of carrying it folded over his arm, or flung across his shoulder, as I had told him, he had rolled it in a ball and was holding it with both hands, on his belly. ${ }^{18}$

Later, after a fatal altercation with a stranger ('his head in a pulp'19) Moran lay down by the fire he had lit earlier and spread his son's raincoat over himself (his son had gone to buy a bicycle). He did not get much sleep, but he got some. In the morning he struck camp, folded the raincoat over his arm and went on his way. ${ }^{20}$

The careful, even tender, treatment that Moran affords the raincoat is all the more striking given that it occurs within an account of a killing of a stranger. The raincoat embodies/is his son. There are echoes of the way in which the man in Flat Landscape holds his cloak over his arm. His arm is right-angled in a position that will surely cause discomfort before long; you sense the pose would be more fitting in a town where others might admire his style.

But again, what if Moran and his son were mother and daughter. How different that would be! 
One day I saw the frame of the painting as if for the first time. It is heavily decorated with foliage but does not overwhelm the man and child, it holds them. It was as though I myself could imagine being surrounded by such a swirling, natural presence; I could tolerate being held together by someone other than myself. I did not know whether the frame was made of wood or plaster, nor did I know the substance of the frame I have around me though I do know I have one.

*

On another visit it is smaller than I expected it to be, and I see into the darkness of the woods on the left and the rickety fence that encloses it.

$*$

When as a child I was car sick, they said look into the distance, not down inside the car, into the distance; there's relief in distance.

$*$

Bereavement closes down the mind when what is needed is an open state of mind in order to deal with the flood of incomprehension. Something more interesting happens when I allow myself to be affected by the paintings rather than when I seek knowledge or guidance from them. Something happens if I move beyond a search for kinship between myself and them: kinship brings condolence which does not move me into a new place. Affective knowing removes some fear and so opens a door.

A riposte to the well-meaning 'I don't know how you bear it': it isn't about bearing or fortitude or being unflinching, but of doing something with the grief. Not carrying the load but tossing it about. I search the painting for connections with my state of mind; they don't need to be overt: something small such as a child's hand held or firewood carried amidst the great expanse is enough. It's when I see these details that I know I'm alive, more than surviving.

He holds the child as he would a walking stick.

In a sequence of five poems called At Yale, Milosz draws out small figures in landscapes by J.M.W. Turner, John Constable and Jean Baptiste Corot.

'And most important, a peasant woman in a red

Skirt, a black bodice, a white

Blouse, carrying something (laundry to the stream?), 
and

'Here are three women, another is riding

A donkey, a man is rolling a barrel, ${ }^{21}$

These small figures in landscapes are anchors for Milosz's meditations about luminosity, goodness, and harmony. I hold tight to my actual, small, lost figure, I do not want to pass beyond her to grander reveries.

In the same sequence, Milosz quotes Baudelaire who quotes Balzac. It seems that a portrayal in a melancholic landscape of 'a small house out of which meagre smoke ascended' prompted Balzac to contemplate the circumstances of the peasants living in the house: 'What do they think about, what are their worries? Did they have a good harvest?' In response, Baudelaire writes: 'I often will appraise a painting uniquely by the sum of ideas or reveries which it brings to my mind. ${ }^{22}$ Apart from wondering where they might be walking to, I had not considered the circumstances of the men in Flat Landscape or Ali Pather. Such is the self-absorption of grief.

She was wearing a grey dress she had bought for the occasion (the holiday occasion).

$*$

A stranger's evocation of a landscape, or in the case of Milosz, a poet's evocation of a painter's evocation, enlivens my imagination and so helps me to realise it. Or maybe it is not so strange since these are common landscapes of feeling that arise whenever life and death are contemplated. They invite an expansion of myself into narrative and into others, away from the isolation of grief.

And the viewing of the paintings takes place within a public gallery - a place that has been set aside for contemplation (though this is less the case today as galleries mimic more and more everyday commercial and hyperactive life). The paintings are a resonant form that I can use to realise, externally, internal emotional states. They propose a form for the abstracted and solitary (non-figurative) experience of grief. They don't assuage it, they acknowledge it and afford it a greater presence.

\footnotetext{
'Sometimes a landscape seems to be less a setting for the life of its inhabitants than a curtain behind which their struggles, achievements and accidents take place. ${ }^{23}$
} 
I have been looking for a setting, a place to put myself. The valley of the Wiltshire Avon on the edge of Salisbury Plain, and the old house I grew up in are the spatial settings from which my internal landscape is formed. This is where I start from.

Parent and child rub along together, they find life through each other's form.

\section{ABOUT THE AUTHOR}

Myna Trustram worked for many years as a curator in museums and galleries in England. Now she is a member of the Manchester School of Art in Manchester Metropolitan University where she runs the training programme for arts and humanities PhD students. She is the author of scholarly publications in museology and British nineteenth century social history (Women of the Regiment: Marriage and the Victorian Army, Cambridge University Press, 1984). Currently she writes experimental essays in response to loss and material culture and informed by psychoanalysis. Email:m.trustram@uwclub.net

\section{NOTES}

1 Gerson, Horst. Philips Koninck. Berlin: Gebr. Mann, 1980 [1935] (103).

2 A diligent search has been carried out for the copyright owner of the work. The rights will be applied for if the owner comes forth.

3 In Milosz, Czeslaw. Facing the River. Trans. the author and Robert Hass. Manchester: Carcanet, 1995.

4 Milosz, Czeslaw. Visions from San Francisco Bay. Trans. Richard Lourie. Manchester: Carcanet, 1982 [1969] (3).

5 Winnicott, D. W. Playing and Reality. London: Penguin, 1988 [1971] (64).

6 Milner, Marion. On Not Being Able to Paint. London: Heinemann Educational Books, 1977 [1950]. Clark, T. J. The Sight of Death. An Experiment in Art Writing. New Haven and London: Yale University Press, 2006.

7 Clark 2006 (133).

8 Idem (202). Milner (1977) [1950] (164).

9 Milner 1977 [1950] (25).

10 Clark 2006 (8).

11 Ibidem.

12 Stevenson, Anne. Elizabeth Bishop. New York: Twayne, 1966 (66).

13 The caption to the painting in Manchester Art Gallery, 2019.

14 Winnicott 1988 [1971] (64).

15 Winnicott 1988 [1971] (74).

16 Beckett, Samuel. Three Novels. Molloy, Malone Dies, The Unnamable. New York: Grove Press, 1955 (4).

17 Beckett 1955 (9).

18 Beckett 1955 (124). 
19 Beckett 1955 (145).

20 Beckett 1955 (147, 153).

21 Milosz, Czeslaw. New and Collected Poems 1931-2001. London: Penguin, 2005 (516).

22 Milosz 2005, New and Collected (519).

23 Berger, John and Jean Mohr. A Fortunate Man. London: Royal College of General Practitioners, 2003 [1967] 2003 (13). 